Génét. Sél. Evol., 1987, 19 (4), 391-398

\title{
Cytogenetic observations on a Robertsonian translocation in Saanen goats ${ }^{(1)}$
}

\author{
I. BURGUETE *, D. DI BERARDINO **, M.B. LIOI **, \\ L. TAIBI ${ }^{* * *}$ and D. MATASSINO $* *$ \\ ${ }^{*}$ Departamento de Genetica y Mejora, Facultad de Veterinaria, Università di Leon, Leon, Espana \\ ** Istituto di Produzione Animale, Facoltà di Agraria, Università di Napoli, \\ 80055 Portici, Napoli, Italy \\ *** Istituto Sperimentale per la Zootecnia di Roma, Sezione Periferica Operativa di Foggia, \\ 71020 Segezia, Foggia, Italy
}

\begin{abstract}
Summary
A Robertsonian translocation of submetacentric type was detected in a herd of 15 goats of the Saanen breed, reared on a farm located in southern Italy. Four males out of 5 , and 2 females out of 10 were found to be carriers of the same translocation in the heterozygous state. All carriers were phenotypically normal.

The RBA banding pattern demonstrated that the centric fusion took place between chromosomes 6 and 15 of the RBA-banded karyotype recently proposed as "standard " for the species Capra hircus L. The C-banding pattern showed the presence of 2 blocks of constitutive heterochromatin, corresponding to the centromeres of the 2 chromosomes involved in the fusion. Silver staining revealed telomeric nucleolus organizer regions on the long arm of the two-armed chromosome.
\end{abstract}

Key words : Robertsonian translocation, goat, chromosomes.

\section{Résumé}

Etude cytogénétique d'une fusion centrique chez la chèvre Saanen

Une translocation robertsonienne submétacentrique a été détectée dans un troupeau de chèvres (Capra hircus L.) de race Saanen, élevé en Italie méridionale. Quatre mâles sur 5 et 2 femelles sur 10 ont été trouvés porteurs de la même anomalie à l'état hétérozygote. Tous les porteurs avaient un phénotype normal.

La technique des bandes RBA a permis de montrer que les chromosomes impliqués dans la translocation sont les chromosomes $\mathrm{n}^{\circ} 6$ et $\mathrm{n}^{\circ} 15$ du caryotype à bandes $\mathrm{R}$ récemment proposé comme "standard" de la chèvre. La technique des bandes $\mathrm{C}$ a permis d'observer, dans le chromosome fusionné, la présence des 2 blocs d'hétérochromatine constitutive correspondant aux centromères des 2 chromosomes fusionnés. La technique du nitrate d'argent a révélé la présence des organisateurs nucléolaires dans les télomères du bras long du chromosome fusionné, correspondant au chromosome $n^{\circ} 6$.

Mots clés : Translocation robertsonienne, chèvre, chromosomes.

(1) This work was supported by a grant from the Research National Council of Rome, Italy. 


\section{Introduction}

The karyotype of the goat (Capra hircus L., $2 n=60$ ), described for the first time by Makino $(1943 ; 1950)$ and subsequently by Gimenez \& Lopez SAez (1962) and Basrur \& Coubrough (1964), consists of 30 pairs of chromosomes, of which 29 are autosomes, all acrocentrics. The $\mathrm{X}$ chromosome is considered to be one of the largest in size, while the $Y$ chromosome is the smallest, metacentric, and therefore, easily identifiable in conventionally stained cytological preparations.

Cytogenic analysis of the goat has so far been limited by the lack of a reliable «standard " banded karyotype. The Reading Conference (ForD et al., 1980) provided a «standard " G-banded karyotype, but in the Bovidae it is well known that the degree of resolution of the G-banding technique is not at all satisfactory, especially for the smallest autosomes. For this reason, several authors (Popescu, 1972 ; Gustavsson \& Hageltorn, 1976 ; Di Berardino \& IANnuzzi, 1982, 1984 ; Di Berardino et al., 1985 a) pointed out the usefulness of using a more reliable banding procedure, such as the RBA technique, for a definite identification of Bovidae chromosomes.

The RBA-banded karyotype of the goat has been recently proposed (Di BERARDINo et al., in press) in order to provide a basis for the definition of the "standard " RBAbanded karyotype for this species, which can be highly useful not only for the correct identification of the chromosomes involved in numerical and/or structural aberrations, but also for chromosome mapping and for studying cytotaxonomic relationships among the members of the family Bovidae.

This paper presents a Robertsonian translocation in Saanen goats, cytogenetically characterized by RBA-banding, C-banding and NOR-staining.

\section{Materials and methods}

The cytogenetic investigation was carried out on a group of 15 Saanen goats ( 5 males and 10 females), reared on a farm located in southern Italy.

Peripheral blood was drawn from the jugular vein and cultured according to the following schedule :

a) Conventional cultures. $0.7 \mathrm{ml}$ of whole blood was cultured in $10 \mathrm{ml}$ of RPMI 1640 medium (Gibco), enriched with 10 p. 100 fetal calf serum (FCS, Gibco), $0.1 \mathrm{ml}$ of L-glutamine and $0.1 \mathrm{ml}$ of Pokeweed mitogen (Gibco), for 72 hours. Two hours before harvesting, colcemid (Gibco, $0.1 \mathrm{ug} / \mathrm{ml}$, final concentration) was added to stop mitosis.

b) Thymidine synchronized cultures for RBA-banding. The cell cultures, prepared as above, were synchronized 48 hours after the initiation by adding excess of thymidine (Sigma, $0.3 \mathrm{mg} / \mathrm{ml}$, final concentration). After 18 hours the S-phase block was released by washing the cells twice with fresh RMPI medium; the cells were again allowed to grow in RPMI medium as in the starting conditions, with the addition of $5^{\prime}$-BrdU (Sigma, $10^{-4} \mathrm{M}$, final concentration) to induce RBA-banding. In order to reduce chromosome contraction, 1 hour later the fluorochrome H33258 (Hoechst) was added at a final concentration of $10^{-4} \mathrm{M}$. The best recovery time was found to be around 5-6 hours. One hour before harvesting, the cells were blocked mostly in prometaphase stage by adding colcemid $(0.05 \mathrm{ug} / \mathrm{ml}$, final concentration). 
c) Cytological preparations. After harvesting, the cells were treated with hypotonic solution $(\mathrm{KC1}, 0.075 \mathrm{M})$ for $20 \mathrm{~min}$ at $37.5^{\circ} \mathrm{C}$ and fixed 3 times with methanol-acetic acid solution (3:1). The fixed cell suspension was dropped onto clean slides and air dried. 1984).

d) $R B A$-banding. It was performed according to Di Berardino \& IANNUZzI (1982,

e) C-banding. It was carried out according to SUMNER (1972).

f) Nucleolus Organizer Regions (Ag-NORs). NOR visualization was performed according to BLOOM \& GoodPasture (1976).

\section{Results}

Of the 15 animals examined, 4 males out of 5 and 2 females out of 10 were found to be carriers of the same Robertsonian translocation of submetacentric type in the heterozygous state. All carriers were phenotypically normal.

Figure 1 shows a conventionally stained metaphase plate of a male Saanen carrier of the translocation $(2 n=59, X Y ; T)$.

The chromosomes involved in the Robertsonian fusion have been identified by RBA-banding as $n^{\circ} 6$ and $n^{\circ} 15$ of the RBA-banded karyotype recently proposed as " standard" for the goat (Di BERARDino et al., in press) ; the 2 fused chromosomes correspond exactly in banding pattern to the autosomes 6 and 15 of cattle (DI Berardino et al., 1985 a).

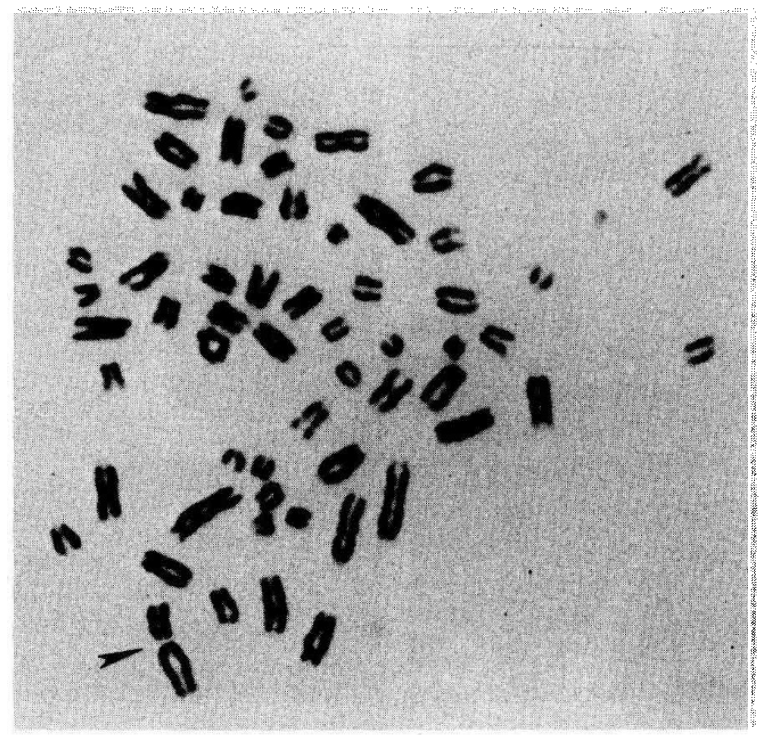

FIG. 1

Conventionally stained metaphase plate of a male Saanen goat carrier of the Robertsonian translocation (arrow). 

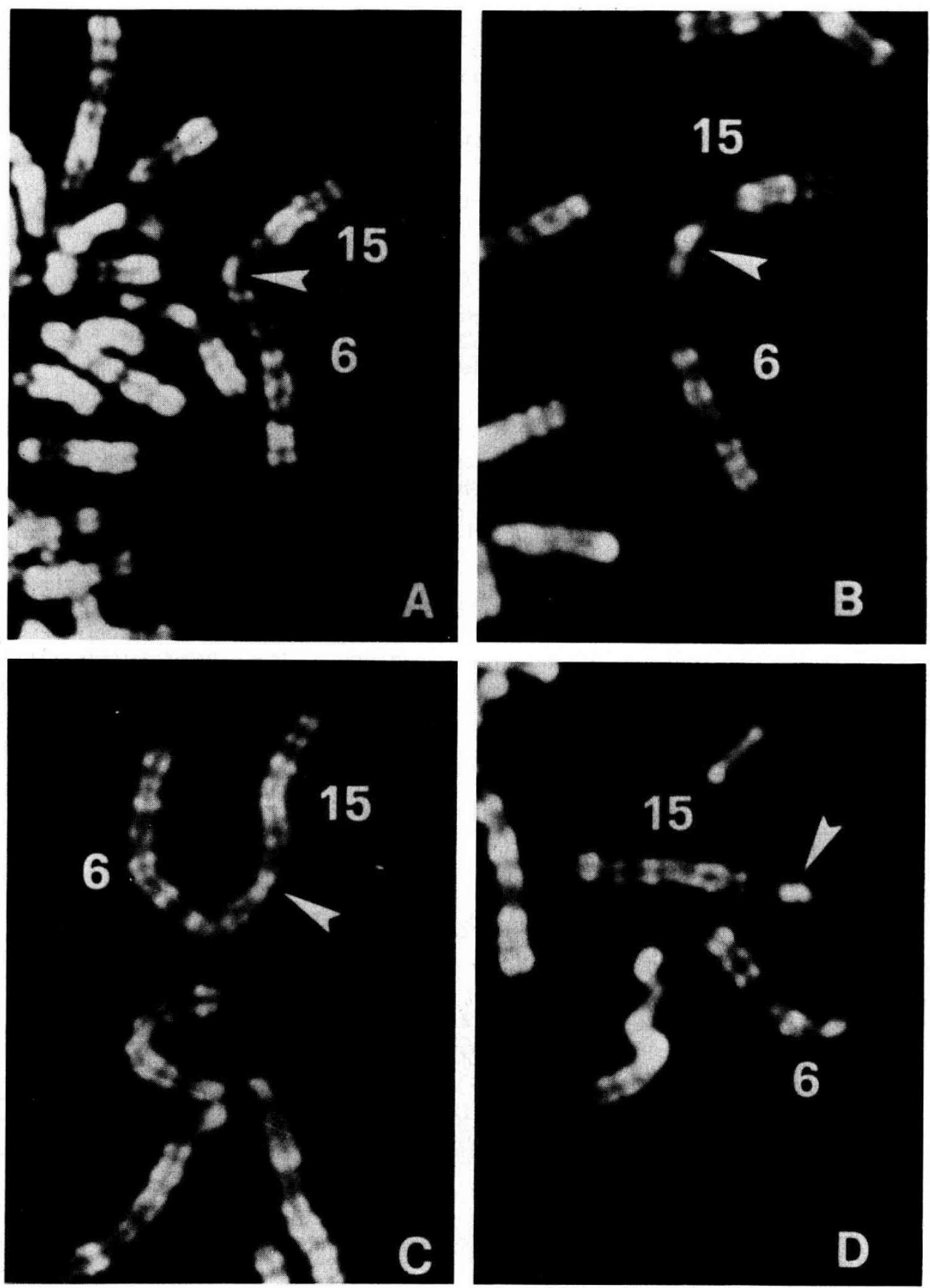

Fig. 2 (A, B, C, D)

Partial RBA-banded metaphase plates showing the translocation $6 / 15$ in different stages of contraction. Arrows indicate the centromeric junction of the 2 chromosomes involved in the fusion. 

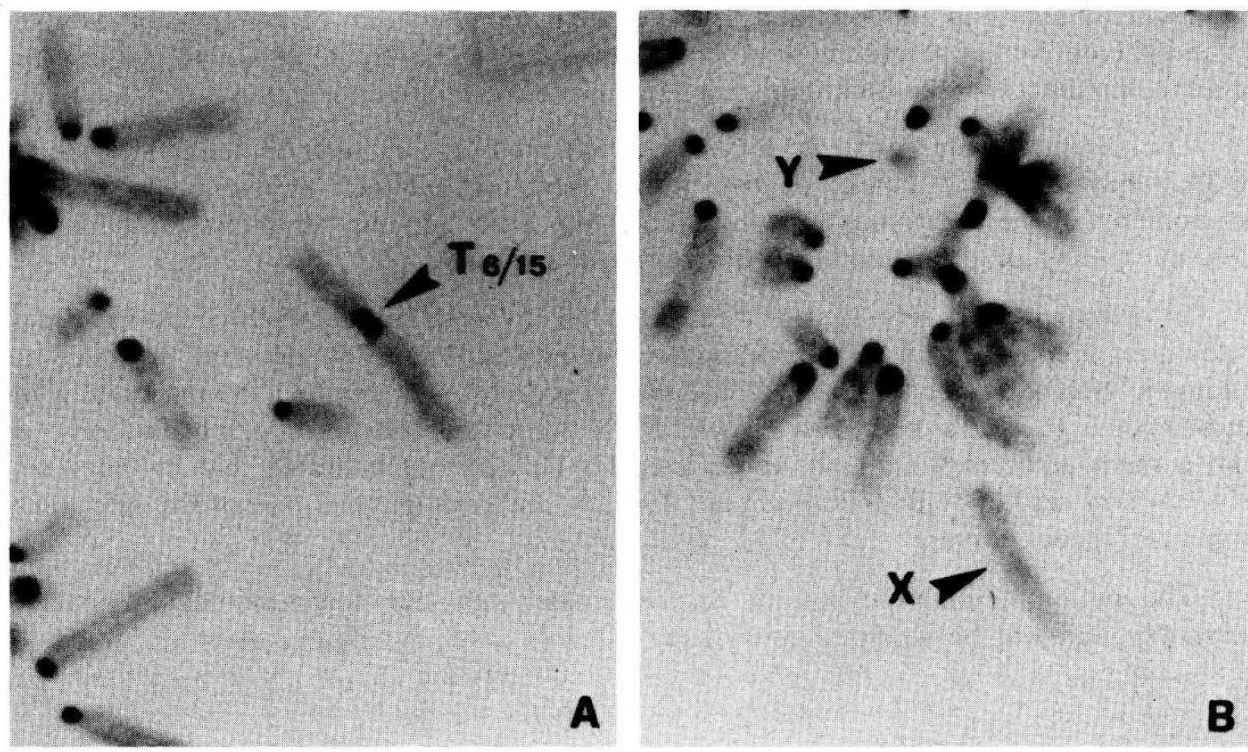

Fig. 3 (A, B)

Partial C-banded metaphase plates showing the dicentric nature of the translocation 6/15 (A) and the negative $C$-band staining of the $X$ and $Y$ chromosomus (B).
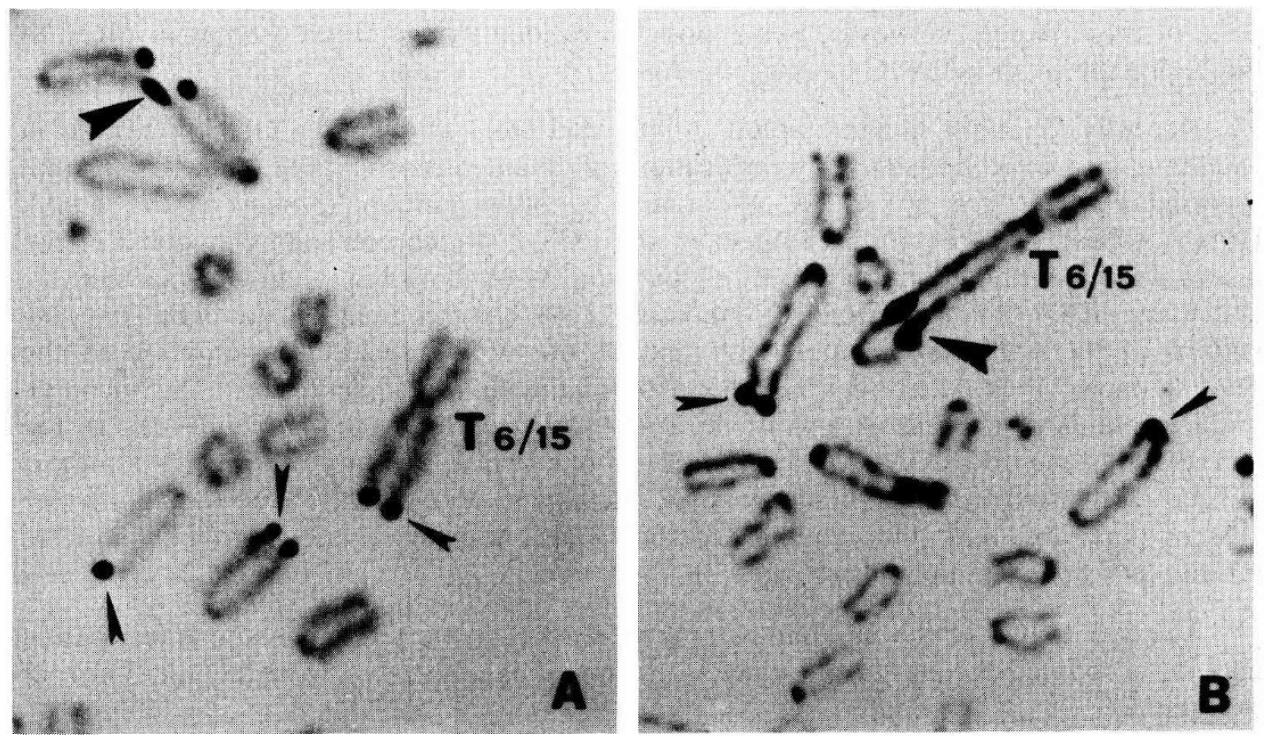

Fig. 4 (A, B)

Partial silver stained metaphase plates showing telomeric Ag-NORs on the long arm of the translocation $6 / 15(A)$ and a nucleolar association between the T6/15 and a small acrocentric $(B)$. Small arrows indicate the telomeric Ag-NORs, large arrows point to the nucleolar associations. 
Figure 2 shows in A, B, C and D the RBA-banding pattern of the translocation 6 / 15 in different stages of chromosome contraction. From this figure it is also possible to observe, in the two-armed chromosome, the presence of 2 centromeres.

The dicentric nature of the translocated chromosome is further defined by figure $3 \mathrm{~A}$ which shows 2 blocks of constitutive heterochromatin, corresponding to the centromeres of the 2 chromosomes involved in the fusion. Figure $3 \mathrm{~B}$ shows the negative $\mathrm{C}$-band staining of the $\mathrm{X}$ and $\mathrm{Y}$ chromosomes.

In order to verify whether the centric fusion involved nucleolar chromosomes, the cytological preparations were stained with silver nitrate. Figure 4 shows the presence of telomeric NORs on the long arm of the two-armed chromosome (A), corresponding to chromosome 6 , and a nucleolar association between the telomeres of chromosome 6 and a small acrocentric, not yet identified (B). This finding indicates that in the goat, as well as in cattle (Di Berardino et al., 1985 b), chromosome 6 is one of the nucleolus organizer chromosomes.

The definitive identification of the nucleolus organizer chromosomes in goat is underway and will be reported elsewhere.

\section{Discussion and conclusion}

Previous cytogenic studies reported in the Saanen goat, the recurrent presence of a Robertsonian translocation of submetacentric type (PADEH et al., 1965 ; Soller et al., 1966 ; Hulot, 1969 ; PAdeh et al., 1971 ; Popescu, 1972 ; Sohrab et al., 1973) ; in none of these papers, however, was it possible to identify the chromosomes involved in the fusion or to visualize C-banding or Ag-NORs.

Recently, Elmiger \& Stranzinger (1982) and Dolf \& Hediger (1984) reported in Saanen goats a Robertsonian translocation of submetacentric type, similar to that reported by PADEH et al., $(1965,1971)$ and by other authors (Soller et al., 1966 ; Hulot, 1969 ; Popescu, 1972 ; Sohrab et al., 1973) ; the chromosomes involved in the fusion were identified as $n^{\circ} 6$ and $n^{\circ} 17$ by using G-banding (Elmiger \& Stranzinger, 1982) and RBA-banding (DolF \& Hediger, 1984). By comparing the RBA-banding pattern of the $6 / 17$ translocation with that of the $6 / 15$ translocation reported in the present paper, it is quite evident we are dealing with the same fusion. The inconsistency in numbering the short arm of the translocated chromosome is mainly due to the lack of a «standard » RBA-banded karyotype but also to the fact the previous authors utilized fairly contracted chromosomes for their G-banding and RBA-banding. In the present paper we used prometaphase chromosomes which are known to be far more informative than the metaphase ones.

The fact that 6 of the 15 animals examined were carriers of the same translocation may be accounted for by the high level of inbreeding associated with the small size of the herd.

It would have been of interest to examine the productive and reproductive performances of the translocation carriers but, unfortunately, at the time of this investigation the animals had just started reproduction. Specific matings, however, have been planned among the carriers of translocation $6 / 15$ in order to attempt fixation of 
the translocation in the homozygous state and to study the segregational patterns of the two-armed chromosome in the progeny.

The dicentric nature of the translocation 6/15 suggests that the fusion event took place quite recently and, therefore, may be considered unstable from an evolutionary point of view. According to NiebHur (1972), in fact, dicentric chromosomes which originated « via » centric fusion may, sooner or later, dissociate again, unless one of the 2 centromeres is eliminated or functionally inactivated.

If the translocation reported in the present paper is the same as that described by PADEH et al. (1965) and subsequently, by other authors, then the translocation 6/15 could be, in the Saanen goat, of practical and biological significance; this hypothesis, however, remains to be demonstrated. By examining the morphology of the two-armed chromosome under conventional staining it is likely we are dealing with the same translocation ; after all, PoPESCu (1972) already has suggested the possibility that the centric fusion reported in his paper might be identical with the fusions reported since 1965.

The large amount of cytogenetic information achieved in the Saanen breed contrasts with the lack of cytogenetic investigations concerning other breeds of goat. Only recently, DolF \& HeDiger (1984) reported in a male goat of the Toggenburg breed a Robertsonian translocation also of submetacentric type, which involved two autosomes not identified by the authors; these chromosomes, according to the RBA-banded karyotype recently proposed (Di BERARDINo et al., in press) are $n^{\circ} 3$ and $n^{\circ} 7$. No other cases, as far as we know, have been reported in the literature.

The increasing diffusion of the Saanen goat in the world and the lack of cytogenetic screening of the imported-exported animals may account for the large incidence of Robertsonian translocations in this breed, but many other questions arise, concerning the origin and the biological meaning of the centric fusions, which remain to be answered.

All this suggests the need to extend the cytogenetic investigations to all the goat populations reared in Italy as well as in other countries, in order to evaluate the real incidence of the Robertsonian translocations, in general, and that of the T6/15 in particular.

Received December 5, 1986. Accepted April 10, 1987.

\section{References}

Basrur P.K., Coubrough R.T., 1964. Anatomical and cytological sex of Saanen goat. Cytogenetics, 3, 414-426.

Bloom S.E., Goodpasture C., 1976. An improved technique for selective silver staining of nucleolar organizer regions in human chromosomes. Hum. Genet., 34, 199-206.

Di Berardino D., Iannuzzi L., 1982. Detailed description of R-banded bovine chromosomes. $J$. Hered., 73, 434-438.

Di Berardino D., IAnnuzzi L., 1984. Detailed description of RBA-banded chromosomes of river buffalo (Bubalus bubalis L.). Génét. Sél. Evol., 16, 249-260.

Di Berardino D., IANnuzzi L., Lior M.B., 1985 a. The high resolution RBA-banding pattern of bovine chromosomes. Cytogenet. Cell Genet., 39, 136-139. 
Di Berardino D., Lio M.B., Iannuzzi L., 1985 b. Identification of nucleolus organizer chromosomes in cattle (Bos taurus L.) by sequential silver staining + RBA-banding. Caryologia, 38, 95-102.

Di Berardino D., Ronne M., Burguete I., Lioi M.B., Taibi L., Matassino D., 1987. The Rbanding pattern of the prometaphase chromosomes of the goat (Capra hircus L.). J. Hered., in press.

Dolf I., Hediger R., 1984. Comparison of centric fusions in a Toggenburg and a Saanen goat, 6th Eur. Colloq. Cytogenet. Dom. Anim., Zürich, July 16-20, 1984, 311-312, Fed. Inst. Techn. (ETH), Zürich.

Elmiger B., Stranzinger G., 1982. Identification of a centromeric fusion in the G-banding karyotype of a Saanen goat. 5th Eur. Colloq. Cytogenet. Dom. Anim., Gargnano (Milano), June 7-11, 1982, 407-409, Ist. Zoot. Gen., Univ. Milano, Milano.

Ford C.E., Pollock D.L., Gustavsson I., 1980. Proceedings of the First International Conference for the Standardisation of Banded Karyotypes of Domestic Animals. Hereditas, 92, 142-162.

Gimenez G., Lopez Saez J.F., 1962. Dotaciones cromosomes en los mamiferos domesticos. Genet. Iber., 14, 7-17.

Gustavsson I., Hageltorn M., 1976. Staining technique for definite identification of individual cattle chromosomes in routine analysis. J. Hered., 67, 175-178.

Hulot F., 1969. Nouveau cas de fusion centrique chez la chèvre domestique (Capra hircus L.). Ann. Génét. Sél. Anim., 1, 175-176.

Makino S., 1943. The chromosome complexes in goat (Capra hircus L.) and sheep (Ovis aries L.) and their relationships. Chromosomes studies in domestic Mammals, II, Cytologia, 13, 39-54.

Makino S., 1950. Constitution of the sex chromosomes in a intersex goat. Pap. Coord. Comm. Res. Genet., 1, 1-3.

Niebhur E., 1972. Dicentric and monocentric Robertsonian translocations in man. Humangenetik, 16, $217-226$.

Padeh B., Wysoki M., Ayalon N., Soller M., 1965. An XX/XY hermaphrodite in the goat. Israel J. Med. Sci., 398, 1008-1012.

Padeh B., Wysoki M., Soller M., 1971. Further studies on a Robertsonian translocation in the Saanen dairy goat. Cytogenetics, 10, 61-69.

Popescu C.P., 1972. Mode de transmission d'une fusion centrique dans la descendance d'un bouc (Capra hircus L.) hétérozygote. Ann. Génét. Sél. Anim., 4, 355-361.

Sohrab M., McGovern P.T., Hancock J.L., 1973. Two anomalies of the goat karyotype. Res. Vet. Sci., 15, 81-87.

Soller M., Wysoki M. PAdeh B., 1966. A chromosomal abnormality in phenotypically normal Saanen goats. Cytogenetics, 5, 88-93.

Sumner A.T., 1972. A simple technique for demonstrating centromeric heterochromatin. Exp. Cell. Res., 75, 304-306. 